\title{
Novela anticlerical y traducción en el Trienio Liberal. Diderot, Lewis y Radcliffe en España
}

\author{
Helena ESTABLIER PÉREZ \\ Universidad de Alicante \\ Helena.Establier@ua.es
}

\begin{abstract}
RESUMEN
Entre 1820 y 1822, es decir, durante el Trienio Liberal, tres novelas europeas de temática anticlerical (dos del ámbito anglosajón y una francesa), publicadas en el último lustro del siglo anterior, se traducen por vez primera a nuestro idioma: La religiosa (1821) de Denis Diderot, El confesonario de los penitentes negros (1821) de Ann Radcliffe y El fraile (1822) de Matthew G. Lewis. La omisión de las tres obras citadas anteriormente de Diderot, Radcliffe y Lewis -textos enormememente populares en la narrativa europea finisecular pero casi desconocidos en nuestro país- dentro del fervor traductor que caracteriza a la literatura española del período, encuentra su explicación en el parentesco de dichos textos con la ficción gótica, género muy poco frecuentado por nuestra literatura nacional de entresiglos, en las libertades que los tres se permiten a la hora de tratar la materia clerical y en la lectura política, incómoda para el absolutismo, que de ellos se deriva. El estudio de dichas cuestiones nos permitirá entender mejor la proyección ideológica que estos textos podrían haber alcanzado en la España borbónica, las razones por las que no aparecieron en ella hasta la etapa constitucional y las causas que explican el que alguna de ellas (El fraile de Lewis) lo hiciera por fin durante el Trienio en una versión mutilada.
\end{abstract}

Palabras clave: Novela, traducción, Trienio Liberal, anticlericalismo, siglo XIX, Diderot, Lewis, Radcliffe.

\begin{abstract}
Between 1820 and 1822, during the so called "Trienio Liberal", three European anticlerical novels, published at the end of the previous century, were translated into Spanish for the first time, namely, Denis Diderot's La religiosa (1821), Ann Radcliffe's El confesonario de los penitentes negros (1821) and Matthew G. Lewis' El fraile (1822). Taking into consideration the large number of translations in the first decades of the 19th Century, the omission of these books -very popular in the European narrative after the turn-of-thecentury but almost unknown in our country- can only be explained attending to three reasons: their relationship with Gothic fiction - a very unusual genre in the Spanish narrative-, their treatment of the catholic religion, and their treatment of political issues critical with the absolutism of the monarchical power. The study of these three aspects will allow us to better understand the ideological projection that these texts might have reached in the Spain under the Bourbons, as well as the reasons that prevented their appearance before the "Trienio Liberal" which also explain why one of them (Lewis' El fraile) could only be published in a mutilated version.
\end{abstract}


Keywords: Novel, translation, Trienio Liberal, anticlericalism, 19th Century, Diderot, Lewis, Radcliffe.

El 11 de marzo de 1820, tan solo dos días después de que Fernando VII jurara la Constitución de 1812 y tras un sexenio de férreo control gubernamental sobre cualquier atisbo de manifestación ideológica contraria a los intereses del régimen monárquico, la Junta provisional Consultiva de Gobierno decretaba la libertad de imprenta. Recuperando la legislación gaditana de 1810 a este respecto, se suprimía la censura previa de los escritos, y -a excepción de las manifestaciones de contenido religioso, sometidas aún a los tribunales eclesiásticos- se introducía una libertad total en materia de reflexión política. Aunque unos meses después -tras la reunión de las Cortes de 26 de junio de 1820- se reinstauró la Junta Suprema de Censura de 1813, que se complementaba, en octubre de ese mismo año, con un decreto para reglamentar la libertad de imprenta desde posiciones claramente moderadas $^{1}$, no cabe la menor duda de que los intelectuales españoles de vocación liberal se desquitaron durante el Trienio -especialmente en sus primeros tiempos- de las restricciones sufridas en el sexenio absolutista, y en distintas manifestaciones escritas dieron rienda suelta a la reivindicación exaltada de las posiciones ideológicas que habían mantenido prudentemente larvadas en el período anterior ${ }^{2}$.

Así, el debate político, que por obra y gracia del constitucionalismo reinstaurado regresaba al órgano fundamental de la vida pública española, las Cortes, tomaba cuerpo en la reflexión escrita del momento, fundamentalmente en la prensa, cuya efervescencia fue espectacular durante el Trienio, pero también en la prosa ensayística y en la literatura, que actuaron en no pocas ocasiones como plataformas de difusión de las consignas liberales y de sus temas predilectos. En este sentido, uno de los motivos favoritos de los escritos de signo liberal producidos en la etapa constitucional lo constituye el planteamiento, desde posiciones más o menos radicales, de la llamada «cuestión clerical», que, desde sus primeros brotes en tiempos de la Ilustración, sólo había conseguido volver con cierta virulencia al panorama político en el interludio gaditano, para quedar después, con la vuelta del Deseado, forzosamente acallada.

Efectivamente, al menos desde mediados del siglo XVIII, las viejas posiciones regalistas de la monarquía, deseosa de imponer su autoridad sobre el cuerpo eclesiástico, se habían reforzado con la insistencia de las élites ilustradas y de un sector del propio clero -minoritario, pero no por ello menos significativo- en la necesidad de una reforma estructural en el seno de la Iglesia, que garantizara

\footnotetext{
${ }^{1}$ C. Morange (1990), p. 89.

${ }^{2}$ Ver, a este propósito, el estudio de E. La Parra sobre la libertad de imprenta en las Cortes de Cádiz (1984).
} 
simultáneamente una restricción del poder del clero regular y la difusión de una religiosidad útil, más acorde con el nuevo racionalismo emergente. La religiosidad ilustrada, de tintes filojansenistas, afrontó con vocación renovadora la patente decadencia de las órdenes regulares ${ }^{3}$, a las que se reprochaba una cierta laxitud moral y un alejamiento progresivo de los principios de austeridad y humildad propios del cristianismo primitivo; recordemos que los ministros de Carlos III y Carlos IV defendieron el control del poder civil sobre diversas materias de disciplina eclesiástica, y que este intervencionismo estatal llegó a materializarse en algunas medidas concretas como la supresión de la compañía de Jesús, la reforma de numerosas congregaciones religiosas o la prohibición de la entrega de nuevos hábitos ${ }^{4}$.

En cualquier caso, fuera por las convicciones religiosas de los propios ilustrados, quienes, como bien señala La Parra, fundan su conducta en los principios del catolicismo y en sus máximas morales ${ }^{5}$, por las disensiones existentes entre ellos, por la presión de los sectores más conservadores de la Iglesia española o por la permanente sombra de la Inquisición, lo cierto es que cuando se traspasa la frontera del nuevo siglo, los tibios envites anticlericales del Estado a lo largo del XVIII no habían dado grandes frutos. Eso sí, habían sentado las bases para el afán críticoreformista del período constitucional, y también -con el interludio del sexenio absolutista, cimentado de nuevo en la alianza entre Trono y Altar característica del Antiguo Régimen- para el anticlericalismo desatado que caracteriza el Trienio Liberal.

Efectivamente, en este breve e intenso período comprendido entre los meses anteriores al levantamiento de Riego en enero de 1821 y la marcha sobre nuestro país de los Cien Mil Hijos de San Luis en marzo de 1823, persiste la voluntad reformista y desacralizadora que ya se había hecho patente en la Ilustración y en las Cortes de Cádiz, pero aderezada ahora, tras el triunfo de liberalismo, con la declarada animadversión de la intelectualidad progresista, que, en cuantos medios tiene a su alcance, no escatima las críticas virulentas a la Iglesia Católica y las sátiras mordaces de los defectos de la clerecía. Cierto es que las burlas y ataques a frailes, monjas, clérigos y prelados no constituían una gran novedad, ya que, como mostró Caro Baroja en su historia del anticlericalismo español, estas actitudes habían sido frecuentes en nuestra tradición oral y escrita desde fines de la Edad Media; sin embargo, este anticlericalismo "creyente» ${ }^{6}$, que se limitaba a denunciar y censurar los desórdenes de conducta del clero -con especial hincapié en sus manifestaciones públicas y privadas de lujuria, avaricia e ignorancia-, nunca llegó a

\footnotetext{
${ }^{3}$ Sobre esta cuestión, ver A. L. Cortés Peña: La política religiosa de Carlos III y las órdenes mendicantes (1989).

4 C. M.Rodríguez (1996), pp. 10-11.

${ }^{5}$ E. La Parra (1998), p. 17.

${ }^{6}$ J. Caro Baroja (1980), p. 14.
} 
cuestionar el papel institucional de la Iglesia católica y menos aún sus dogmas. El anticlericalismo decimonónico aporta en este sentido un componente nuevo, al oponerse a cualquier forma de control ideológico de la sociedad por parte de la Iglesia y proponer un modelo de secularización progresiva para el Estado español ${ }^{7}$.

Como bien explica Moliner ${ }^{8}$, se popularizó en el Trienio un tipo de prensa liberal exaltada, en ocasiones satírica y burlesca, y en otros casos seria e incluso erudita, de donde surgieron diversas campañas destinadas a fomentar el anticlericalismo en la opinión pública. A la ofensiva generalizada de periódicos y folletos constitucionalistas se sumó la de la prosa anticlerical y antiinquisitorial ${ }^{9}$, generalmente obra de clérigos reformistas o en la estela del «liberalismo cristiano», bien en forma epistolar (como los Lamentos políticos de un Pobrecito Holgazán [1820] del clérigo afrancesado Sebastián de Miñano, o las Cartas familiares del ciudadano J.J. de Clararrosa a Madama Leocadia del ex franciscano Antonio de Olabarrieta, publicadas en 1822 tras la muerte del autor), de memorias (Viaje al mundo subterráneo del propio Olabarrieta, alias «Clararrosa») o incluso de escritos polemistas (como España venturosa por la vida de la Constitución y la muerte de la Inquisición publicada por el clérigo jansenista Antonio Bernabeu en 1820, o -el mismo año- el Proyecto de constitución religiosa haciendo parte de la constitución civil de una nación libre e independiente, del historiador y ex-secretario de la Inquisición de Corte, Juan Antonio Llorente).

No debemos olvidar, por otro lado, que este anticlericalismo de tintes intelectuales coexistió durante el Trienio con otro de inspiración popular y resultados bastante más cruentos. Azuzado en parte por la ofensiva anticlerical que se lleva a cabo desde la tribuna intelectual, como resultado también de un enconamiento gestado progresivamente durante largos años de preeminencia eclesial, y seguramente para contrarrestar el apoyo del clero a los enemigos del régimen constitucional, determinados sectores populares adoptaron actitudes beligerantes contra espacios y miembros de las comunidades religiosas. De esta forma, a finales del Trienio, a raíz de los enfrentamientos entre las partidas realistas de Fernando VII y los constitucionalistas, este anticlericalismo popular culminó en diversos asaltos a monasterios y conventos, y en el asesinato, a veces atroz, de

${ }^{7}$ J. de la Cueva Merino (2004), p. 354.

${ }^{8}$ A. Moliner (2001), pp. 73-102.

${ }^{9}$ Tal como explica Daniel Muñoz Sempere en su bien documentado estudio La Inquisición española como tema literario, aunque durante las Cortes de Cádiz ya habían circulado en nuestro país textos filosóficos antiinquisitoriales, es realmente en el Trienio -tras la abolición del Tribunal por Fernando VII y la liberación de sus prisioneros- cuando se multiplican los escritos más polémicos sobre el Santo Oficio, enmarcados en ese anticlericalismo radical que caracteriza el período constitucional. (2008, pp. 66-73). 
frailes de las órdenes regulares ${ }^{10}$, con una virulencia que no volverá a repetirse hasta la revolución liberal burguesa de $1834-1835^{11}$.

Algo debió de contribuir también la literatura a este ambiente de exaltación popular, aunque lo cierto es que en este campo las muestras nacionales de furor anticlerical que nos deja el Trienio son más bien escasas. La mayoría de ellas, como ya estudió Caldera ${ }^{12}$, pertenece al ámbito teatral, ya que la novela, que no constituye un género literario de especial desarrollo en la España del primer tercio del $\mathrm{XIX}^{13}$, permanece de forma casi absoluta en el inmovilismo ideológico de la época fernandina, cómodamente instalada en el cultivo de lo didáctico- moral y de lo sentimental.

De hecho, la única novela española de contenido anticlerical que se escribe en el Trienio, Vargas: a Tale of Spain (Londres, 1822), de José María Blanco White, es producto del exilio inglés y no se traduce al español hasta la edición de Benítez y Francés en $1995^{14}$. Esta novela seudo-histórica -que desliza, sobre la odisea del protagonista por librar a su amada de la inicua persecución de la Inquisición sevillana, una mirada más que complaciente al modelo anglicano de libertad y tolerancia social-, se inspira en otra anterior, reeditada en varias ocasiones en el período constitucional pero publicada por vez primera en París en 1801: Cornelia Bororquia o la víctima de la Inquisición. La obrita, del trinitario renegado y autoexiliado en el país vecino, Luis Gutiérrez, había sido considerada lo

${ }^{10}$ E. La Parra (1998), pp. 58-61; (2000), p. 256.

${ }^{11}$ A. Moliner (1997), pp. 497-541.

${ }^{12}$ Señala Caldera que «con la rivoluzione de Riego e il ritorno delle libertà costituzionali, si assiste a una notevole fioritura di opere teatrali politicamente impegnate, in molti delle quali riemerge, con la forza di una rabia troppo a lungo repressa, l'ostilità contro il S. Uffizio» (1985, pp. 28-29). Cita aquí Caldera las siguientes obras de tinte anticlerical, representadas durante el Trienio: La Inquisición, drama original en cuatro actos (1820), El hipócrita pancista, o acontecimientos de Madrid en los días 7 y 8 de marzo del año 1820, comedia en tres actos en prosa por D.F. de P.M. (1820), Virtud y patriotismo, o el $1^{\circ}$ de Enero de 1820 , comedia en un acto por M. Eduardo de Gorostiza (1821), La servil arrepentida, pieza patriótica original en dos actos (1922), Fray Lucas o el monjío deshecho, comedia en verso en cinco actos (1820), El Donado fingido, comedia en dos actos en verso (1823) y La Novicia o la Víctima del claustro, tragedia en tres actos (1820).

Podemos añadir a las citadas Lanuza (1822) de Ángel Saavedra, aunque su contenido anticlerical sea más tangencial, las obras en catalán de Josep Robreño (La fugida de la regència de la Seu d'Urgell y desgràcies del pare Llibori, L'hermano Bunyol, Mossén Anton a les muntanyes del Montseny y El pare Cernot à Guimerà) y, según Moliner, reposiciones del XVII y del XVIII con contenido anticlerical más o menos relevante, como El diablo predicador de Luis de Belmonte o las obras de Moratín (El sí de las niñas, La mojigata). (Moliner, 2001, p. 82)

${ }^{13}$ Ver J.I. Ferreras, Los orígenes de la novela decimonónica (1973).

${ }^{14}$ Ver «Obras citadas», al final de este trabajo. 
suficientemente subversiva como para ser prohibida in totum en 1804 y pasar a formar parte del Apéndice al Índice inquisitorial en 1817 tras la vuelta del Deseado. De hecho, el rapto e intento de violación de la protagonista por el lujurioso arzobispo de Sevilla, el asesinato de un miembro de la Iglesia en defensa propia y la injusta ejecución de la joven a manos de la Inquisición, superaban con creces cualquier expectativa del recién restablecido Santo Tribunal. Por ello, desde entonces hasta 1820, Cornelia Bororquia sólo pudo ver la luz fuera de España (en Londres y París), pero en el Trienio, coincidiendo con la publicación inglesa de Vargas, consigue llegar a las imprentas españolas al menos en cinco ocasiones ${ }^{15}$, lo cual subraya el interés y la actualidad del tema anticlerical y antiinquisitorial dos décadas después de que Gutiérrez lo convirtiera en materia novelesca. A tenor de las indicaciones de García Castañeda acerca del afán de la literatura de la emigración por resaltar los oscuros menesteres del Santo Oficio ${ }^{16}$, no resulta sorprendente que las dos novelas españolas (Vargas y Cornelia) más abiertamente anticlericales del período que estudiamos, se publiquen en el extranjero (Londres y París, respectivamente).

A la vista de que en los últimos tiempos las novelas de José María Blanco White y de Gutiérrez han recibido por fin conveniente y merecida atención crítica ${ }^{17}$, me centraré en otros textos raramente frecuentados por los estudiosos, pero imprescindibles para completar el exiguo panorama que presenta la novela anticlerical autóctona durante el Trienio. Me refiero, claro está, a las traducciones de obras extranjeras, que, como bien nos mostraron Ferreras y Montesinos, y ratificó Pegenaute ${ }^{18}$, constituyen en conjunto un fenómeno literario de singular envergadura e imprescindible en cualquier intento de valorar adecuadamente la narrativa española del primer tercio del siglo XIX.

Entre 1820 y 1823 , tres novelas europeas con temática clerical (dos del ámbito anglosajón y una francesa), publicadas en el último lustro del siglo anterior, se traducen por vez primera a nuestro idioma: La religiosa $(1821)^{19}$ de Denis Diderot,

\footnotetext{
${ }^{15}$ Tomo los datos de la vida editorial de Cornelia de la edición de Dufour (1987), pp. 19-20. Existe también otra edición de Juan Ignacio Ferreras (1994).

${ }^{16}$ S. García Castañeda (1986), pp. 20-34;(1987).

${ }^{17}$ Destacamos, además de las ediciones ya reseñadas de Vargas y de Cornelia Bororquia, las aportaciones de J. Urrutia (1990), A. Garnica (1997), R. P. Sebold (1998), M. R. Malin (2002), S. Dale (2004) y las páginas que dedican a ambas obras J.L. Molina y D. Muñoz Sempere en sus respectivas monografías (1998), pp. 57-76 y (2008), pp. 44-65. Todas ellas se encuentran citadas en la bibliografía final de este trabajo.

${ }^{18}$ José F. Montesinos (1982); Juan I. Ferreras (1973); Luis Pegenaute (2004).

${ }^{19}$ La religieuse fue escrita por Diderot en 1760, aparentemente sin intención de publicarla; finalmente, corregida por su autor, apareció por entregas en La Correspondance Littéraire entre 1780 y 1782 . Su primera versión completa fue publicada en 1796, doce años después de la muerte del autor, por el librero Buisson.
} 
El confesonario de los penitentes negros $(1821)^{20}$ de Ann Radcliffe y El fraile $(1822)^{21}$ de Matthew G. Lewis. No sería este hecho especialmente reseñable, teniendo en cuenta la ingente cantidad de traducciones con las que nos deleitan las primeras décadas del XIX, si no fuera por la extraordinaria repercusión que tales novelas habían tenido en sus países de origen y -en contraste- el absoluto silencio que nuestro país había guardado al respecto durante varias décadas.

La de Diderot, aunque publicada por vez primera en versión completa póstumamente, es en realidad casi cuatro décadas anterior a las otras dos. Cuando el librero Buisson editó la obra en octubre de 1796, en pleno predominio de noticias de índole política y militar en Francia, varios periódicos se refirieron a ella en términos elogiosos. Aunque su componente antimonástico pareció complacer especialmente a los críticos afines al Directorio, quienes, fieles a la tradición de la Convención, seguían obstinados en la búsqueda de armas de propaganda contra el antiguo régimen, lo cierto es que la obra obtuvo también un éxito considerable entre el público lector, del cual dan fe las numerosas reediciones que obtuvo en los tres últimos años del siglo. Sólo en Francia, la edición de 1796 dio lugar a dieciséis reimpresiones, y antes del cambio de siglo, La religieuse ya se había traducido al alemán, al inglés y al italiano ${ }^{22}$. La obra incluye las memorias ficticias de la joven Suzanne Simonin, quien, obligada por su familia a profesar los votos, solicita el auxilio del marqués de Croismare, relatándole con extrema crudeza los tormentos y penalidades a los que se ha visto sometida en diversos conventos para expiar su falta de vocación y su obstinada cruzada por regresar a la vida del siglo, así como los diferentes episodios del «pulso» judicial con el que la joven novicia ha desafiado a la institución eclesiástica. Inspirada en un hecho real, la novela recoge uno de los temas mayores de la sensibilidad literaria de la segunda mitad del XVIII desde Richardson (las pruebas pasadas por una víctima inocente perseguida por la maldad natural de ciertas almas y por una sociedad inhumana), y anuncia ya, a través de la narración del martirio de Suzanne, el «sadismo» de finales de la centuria. El final de la historia es abierto y ambiguo, ya que aunque la monja consigue escapar, auxiliada por un monje benedictino de lúbricas intenciones, el mundo exterior al convento resulta ser, para una joven sin experiencia en la vida civil, tan hostil y peligroso como el de intramuros. La primera versión española la publica Rosa, en París, en 1821, y su portada reza así: «La religiosa; escrita en francés por M. Diderot, de la Academia Francesa. Traducida libremente al español por Don M.V.M., Licenciado».

Excelente acogida tuvo también en su país de origen The Monk (1796), polémica opera prima de Matthew G. Lewis. Si, como hemos señalado, los horrores

\footnotetext{
${ }^{20}$ Es la traducción de The italian, escrita por Ann Radcliffe en 1797.

${ }^{21}$ Es traducción de The Monk, publicada en inglés en 1796.

${ }^{22}$ Tomo los datos del excelente estudio de Georges May, Diderot et «La Religieuse». Étude historique et littéraire (1954), pp. 22-26.
} 
referidos en La religieuse se centran en el ámbito conventual, las tropelías sexuales del padre Ambrosio en el relato gótico de Lewis se extienden aún más allá de los muros del monasterio en el que aquél ejerce de prior. Las páginas del autor inglés, como las de Diderot, transforman en materia literaria el exceso, en este caso el de la pasión y el fanatismo ocultos bajo los velos de la respetabilidad y de la propiedad. La trama principal de la novela comprende la vertiginosa caída moral de un clérigo virtuoso al entrar en contacto con el mundo, y lo hace sin escatimar en horrores, violaciones, crímenes, incestos, parricidios, y cediendo lugar de honor en la narración a toda la parafernalia que rodea el mito faústico: poderes sobrenaturales, conjuros diabólicos, pócimas mágicas, apariciones satánicas, etc. Las víctimas de las liviandades carnales de Ambrosio resultan para mayor escándalo ser su madre, Elvira, a la que asesina para conseguir el acceso a Antonia, y esta última, su propia hermana, que acaba sus días violada y apuñalada por el cura en las catacumbas del monasterio. Ambrosio se salva del castigo de la Inquisición comerciando con su alma, y al final de las casi cuatrocientas páginas de la versión española de la novela, Lucifer se cobra su deuda con la vida del sacrílego sacerdote. La trama secundaria del texto inglés relata la historia de Inés, monja a la fuerza, inhumanamente castigada por sus compañeras por su inclinación a la vida del siglo. Aunque lo cierto es que hoy en día las descripciones de Lewis provocan la sonrisa del lector más pacato, lo explícito de algunas escenas y el ambiente general de depravación, voluptuosidad y lujuria que presenta la novela causó auténtico escándalo entre la crítica de su tiempo, que se debatió entre el reconocimiento hacia la poderosa imaginación del autor y su maestría en el manejo de los resortes del horror, por un lado, y la enconada denuncia de los desórdenes morales que la obra reflejaba con absoluta transparencia, por el otro ${ }^{23}$. Lo cierto es que la novela tuvo tanto éxito que logró dos ediciones más el mismo año de su publicación y creó una nueva corriente «diábólica» en la ficción gótica, con bien nutrida presencia de relatos «de monjes» ${ }^{24}$. Al español se tradujo por vez primera en 1822, en Madrid, con el título

${ }^{23}$ Coleridge es un buen ejemplo de esta ambivalencia que la obra genera en los críticos posteriores. En un artículo significativamente titulado «The blasphemy of The Monk», escrito para Critical Review el mismo año de la publicación de la novela de Lewis, se refería a sus imágenes voluptuosas («voluptouos images») como «poison for youth and a provocative for the debauchee» («veneno para la juventud y una provocación al libertinaje») (p. 198; pp. 198-200)

${ }^{24}$ Por citar algunos ejemplos significativos, es el caso de The Monk of Udolpho (1807), para cuyo título se inspira T.J. Horsley-Curties en Radcliffe y en Lewis. Por su parte, en Zofloya; or the Moor (1806), Charlotte Dacre usa el tema de la condenación faústica en una historia con protagonista femenina, aunque no por ello menos malvada e igualmente tentada por un agente demoníaco. 
de «El fraile ó historia del padre Ambrosio y de la bella Antonia; traducido libremente al español» ${ }^{25}$.

En 1797, Ann Radcliffe, bien conocida ya por sus diversas y populares incursiones en lo gótico-sentimental, da a la luz The italian, en parte para contrarrestar los excesos de Lewis en el género. Su personaje central es también un monje, el padre Schedoni, pero en esta ocasión la villanía y los crímenes del religioso no son «sobrenaturalmente» diabólicos, como los de Ambrosio, sino que sus pérfidas acciones encuentran en el texto explicaciones de lo más prosaicas: los celos y la ambición. Así, la novela de Radcliffe cuenta, como la de Lewis, con un monje acosador, que retiene indignamente a una víctima inocente para evitar su enlace con un joven de la alta nobleza, pero añade la novedad de la madre intrigante, que por puro orgullo de clase convierte a su hijo en víctima de los oscuros manejos del malvado Schedoni. La obligada contención femenina de la autora evita el tema de la lujuria y el desenfreno sexual, y convierte el asunto de la persecución de Ellena, víctima inocente, por el clérigo -que resulta al final ser su tío-, en una mera cuestión de ansia de poder y de oscuros pactos entre la nobleza y la Iglesia en virtud de intereses comunes. Al final, desde luego, no hay incestos ni parricidios como en la novela de Lewis, y aunque el malvado padre Schedoni muere envenenado por otro sacerdote en los calabozos de la Inquisición, la autora, que no se resiste a los finales propios del género sentimental, rescata a los jóvenes virtuosos, quienes recuperan su dignidad y sus apellidos, y se casan por amor. Es de sobra conocido el éxito - de crítica y popular- de las novelas de Ann Radcliffe, que fue la escritora más leída en Inglaterra en la década de los noventa ${ }^{26}$; la más leída, y también la más imitada y traducida. De hecho, sus novelas fueron trasladadas inmediatamente a casi todas las lenguas europeas en un éxito editorial sin precedentes en el continente; no así, sin embargo, al español, que sólo recibe Julia, o los subterráneos del castillo de Mazzini (A Sicilian Romance, 1790) en 1819 y The italian en 1821, con el título El confesonario de los penitentes negros ${ }^{27}$.

Es posible que la omisión de las tres obras citadas anteriormente de Diderot, Radcliffe y Lewis -textos enormememente populares en la narrativa europea

\footnotetext{
${ }^{25}$ Esta edición madrileña, que manejaremos aquí, indica en su portada: «Hállase también en casa de Rosa, en París».

${ }^{26}$ Tomo los datos del estudio sobre la autora de R. Miles, The Great Enchantress, donde cita a su vez el Gentleman's Magazine de 1823 (1995, p. 8).

${ }^{27}$ Esta primera traducción al español se publica en Madrid, en la Imprenta de Brugada, con las siguientes indicaciones en portada: «Escrito por Ana Radcliffe, traducido en francés por Morellet y en castellano por D.T.H. r D.M.S». Existe otra edición de la misma traducción (Málaga, Imprenta y Librería de Andrea Martínez, s.a.), sin duda posterior a 1832, pues recoge en su portada referencia a Radcliffe como autora de Los misterios de Udolfo, obra no trasladada al español hasta esa fecha. Su título es El italiano, o el confesonario de los penitentes negros.
} 
finisecular- dentro del fervor traductor que caracteriza a la literatura española del período, encuentre parcialmente una explicación en el parentesco de dichos textos con un género muy poco frecuentado por nuestra literatura nacional de entresiglos: la ficción gótica o novela negra. Sin olvidar las evidentes diferencias que separan el texto de Diderot de las obras de Radcliffe y Lewis ${ }^{28}$, lo cierto es que los tres autores ponen en juego en sus novelas algunos de los resortes narrativos habituales en los relatos «de horror» o «de terror»-denominaciones con las que también se conocieron en nuestro país los gothic romances o gothic tales-, a los que los lectores españoles del período estaban poco habituados: héroes (o heroínas) rebeldes con dificultades para integrarse en la sociedad y/o definir una identidad individual, personajes negativos que amenazan la unidad social, relaciones humanas insanas y predatorias, instituciones encargadas de representar diferentes formas de opresión sobre los individuos más débiles (religión católica, Inquisición, familia, nobleza corrupta), historias de lujuria y sexualidad reprimida, víctimas inocentes, todo ello ambientado en escenarios terroríficos y sublimes (monasterios con lóbregos subterráneos, celdas de conventos, catacumbas, castillos en ruinas, bosques oscuros y amenazadores, altísimas y escarpadas montañas, etc.).

Lecturas potencialmente subversivas, los relatos góticos fueron recibidos en su mismo país de origen con no poca prevención por parte de críticos y moralistas, que temían el efecto que sus argumentos perversos y sus personajes extremos pudieran causar en los jóvenes lectores. En el nuestro, presidido por el reaccionarismo ideológico fernandino y acostumbrado a una práctica novelística lastrada con pretensiones eduativas y moralizadoras, las muestras autóctonas del horror fueron

${ }^{28}$ De hecho, las obras de Lewis y Radcliffe son consideradas textos canónicos dentro del gótico dieciochesco inglés. A Radcliffe se la suele citar como ejemplo paradigmático de la primera hornada de sucesores de Walpole, fundadora de la escuela del «terror» gótico y de su intangible atmósfera de amenaza espitirual, como un cierto escalofrío supersticioso que insinúa la presencia en la tierra del más allá; mientras tanto, Lewis representa el giro de la novela gótica hacia la crudeza extrema, lo explícitamente macabro, lo violento y lo sobrenatural, es decir, el llamado «horror gótico», «gótico satánico» o «Schauer-Romantik» (D.P. Varma, 1966, pp. 129-132). Diderot no es, desde luego, un escritor de relatos góticos, y de hecho La religiosa destaca fundamentalmente por su tono realista y su enfoque filosófico, más adecuados a una novela de tesis como es esta que la citada afición gótica por lo sobrenatural. No obstante, no dejamos de percibir en ella un cierto regusto gótico (ambiente sombrío y cerrado, voces lúgubres, episodios de locura y delirio, crueldad, alienación, sexualidad furtiva) y, en general, una atmósfera de melancolía, frustración y muerte que evidencia las relaciones literarias entre la novela francesa de la época y el gótico inglés. Sobre las conexiones «góticas» a uno y otro lado del canal, conviene consultar el clásico estudio de M. Lévy, Le Roman 'gothique' anglais 1764-1824 (1968), así como el trabajo de S. Werner «Diderot, Sade and the gothic novel»(1973). 
mínimas $^{29}$, y muy pocas de las principales obras de la ficción gótica inglesa llegaron a traducirse al español. Así, ni The Castle of Otranto (Horace Walpole, 1764), ni Vathek (William T. Beckford, 1786), ni Caleb Williams (William Godwin, 1794), ni The Monk (Matthew G. Lewis, 1796), por citar algunos de los textos del género con mayor carga ideológica, habían tenido hacia 1820 versión española. Sólo la vena sentimental presente en el «gótico femenino» (o «female gothic») $)^{30}$ parecía haber encontrado cierto eco entre los editores y traductores españoles, que sí ofrecieron a sus lectores versiones de obras con resortes góticos al servicio de la aventura amorosa o la intriga histórica, como The Recess (Sophia Lee, 1785), The Children of the Abbey (Regina M. Roche, 1796) o A Sicilian Romance (Ann Radcliffe, 1790).

A la vista de la purga que sufre el género gótico en su camino hacia nuestro mercado editorial, no es de extrañar que obras especialmente transgresoras y polémicas como las citadas de Radcliffe, Lewis o Diderot no llegaran a ver la luz en español hasta el Trienio, especialmente si consideramos que, más allá de la presencia en ellas de los consabidos recursos narrativos popularizados por la corriente gótica, las tres comparten un fondo ideológico común, de difícil aceptación en la España absolutista.

Es más que probable, para empezar, que las libertades que se permiten esos relatos a la hora de tratar la materia clerical constituyeran factor disuasorio de primer orden para su traducción al español, que sólo se produce en el período constitucional, cuando el poder decisorio de la monarquía y de su principal aliada, la Iglesia, sobre el destino de las obras literarias, había quedado transitoriamente en suspenso. Recordemos algunas de las constantes que aparecen en este sentido en las tres novelas:

1- Gran parte de su acción transcurre en escenarios cerrados, ligados a la práctica de la religión católica (monasterios, conventos, calabozos inquisitoriales, Iglesias), que se describen como espacios antinaturales y opresivos. En estos relatos, el retiro del mundo para el ejercicio de la virtud y el perfeccionamiento moral con los que la vida monástica justifica su existencia, parecen producir un efecto inverso en sus seguidores, que exteriorizan las consecuencias de la represión física y moral propia de aquella de los modos más diversos: locura, ira, pasión desenfrenada, incapacidad para controlar las propias emociones, etc.

En La Religiosa, por ejemplo, el relato de las vicisitudes de Suzanne Simonin abarca el paso de la joven novicia por diversos conventos, en los que asistimos a todo género de desórdenes morales causados por la estricta contención de los impulsos naturales que imponen dichas instituciones: la hipocresía y las mentiras del convento de Saint-Marie, la intransigencia, el sadismo y el fanatismo de las

\footnotetext{
${ }^{29}$ Sobre la limitada presencia de la parafernalia gótica en la literatura española de la época, conviene consultar: G. Carnero (1983; 1993), L. A. de Cuenca $(1977 ; 1984)$, J. I. Ferreras (1973, pp. 243-264), E. Caldera (1991) y N. Glendinning (1994).

${ }^{30}$ Ver J. E. Fleenor (1983).
} 
religiosas de Longchamp, la neurosis homosexual de la superiora de Saint-Eutrope, etc. La invectiva de Diderot contra la vida claustral, de una ferocidad sin precedentes $^{31}$, se sustenta en una realidad social de la Francia dieciochesca, ampliamente contrastada desde la literatura y la ensayística religiosa, moral y pedagógica de su tiempo ${ }^{32}$ : la perversión del espíritu original de las instituciones monásticas, las cuales, con la connivencia de las autoridades religiosas y civiles, se habían convertido en auténticos semilleros de vocaciones forzadas, idóneas por su aislamiento para ocultar los abusos de las familias contra la voluntad de las jóvenes.

En las dos novelas inglesas, sin embargo, la elección de conventos y monasterios católicos como escenario de horrores e iniquidades de toda índole no obedece a una vocación realista, ni refleja tampoco una especial voluntad didáctica o preventiva, sino que responde más bien a la fascinación de la Inglaterra protestante de finales del XVIII -y de su literatura- por los ingredientes formales y doctrinales de la Iglesia de Roma, que se entienden como símbolos de una Europa continental caduca, encabezada por regímenes políticos antiguos, tan oscuros como la misma fe religiosa que practican ${ }^{33}$. De ahí que, salvando las diferencias en cuanto a su intención, la reflexión sobre los efectos de la reclusión monástica en el desarrollo

${ }^{31}$ El propio Diderot señalaba a Meisner, editor de la Correspondence Littéraire, en 1780: «Je ne crois pas qu'on ait jamais écrit une plus effroyable satire des couvents» (Cit. por May, 1954, p. 170)

${ }^{32}$ No sólo la literatura «conventual» venía tratando este tema desde el siglo anterior, sino que el asunto se había convertido, a lo largo de la centuria, en asunto habitual de meditación y de exhortación de los oradores eclesiásticos (Bossuet, Bonhomme, Massillon), de los pensadores seglares (Saint-Simon, Voltaire) e incluso de los damaturgos de la Revolución y anteriores a ella (Baculard D'Arnaud, Dubois de Fontanelle).

${ }^{33}$ En su estudio Catholicism in Gothic Fiction (1966), pp. 121-122, Mary M. Tarr estudia 121 ejemplos de ficción gótica, de los cuales 107 incluyen referencias a la religión católica: materiales de culto litúrgico y no litúrgico, vida monástica y conventual, y elementos destinados a crear una atmósfera católica, como ruinas eclesiásticas, capillas, monaterios, conventos, monasterios, cámaras inquisitoriales e iglesias.

Señala Tarr que el análisis de estos materiales revela en la ficción gótica la presencia de dos actitudes hacia la religión católica: cuando la cuestión que se aborda es de tipo intelectual (el dogma católico), la actitud de estos relatos es el ataque contra la superstición monástica. Desde esta perspectiva, Tarr las considera novelas de propaganda, que no sólo dan voz a los principios del librepensamiento deísta, sino que también abordan asuntos como la virtud natural, la simplicidad de la vida rústica, la depravación de la aristocracia o la educación femenina. Por otro lado, cuando los materiales católicos se perciben emocionalmente, como ocurre mayoritariamente en la ficcion gótica, la actitud resultante se expresa en términos de «placer melancólico», «horror divino» o «temor religioso». Concluye Tarr que la ficción gótica refleja, en su tratamiento de los materiales católicos, las tres principales corrientes del pensamiento diceciochesco; la religión natural (Deísmo), la moral natural (la ética propugnada por Shaftesbury) y lo sublime (Burke). 
individual ocupe también un lugar relevante en la novela de Lewis. De hecho, a Ambrosio, educado en el monasterio, se le ha escamoteado el contacto con la vida social y el fluir natural de los impulsos y las emociones. Tal como le cuenta el fraile al falso novicio Rosario - después mujer lasciva y demonio al final- en las primeras páginas del libro, la vida conventual supone en teoría un balance perfecto entre aislamiento y vida comunitaria, un espacio idóneo, preservado de la corrupción del dominio público, para mediar entre el individuo y la sociedad. En la práctica, sin embargo, el claustro no resulta ser ese lugar donde se contienen religión y virtud, sino una metáfora de la represión de la naturaleza (identificada con la sexualidad) y de la idealización ilusoria de la vida espiritual. Opresión, superstición e idolatría ciega pueblan ese mundo de intramuros (el del monasterio dominico y el del convento anejo a él) que, bajo una superficie seductora de paz y elevación espiritual, esconde verdades oscuras y decadentes: la perversión demoníaca de Matilda, enviada por Satán con el disfraz de falso novicio para perder a Ambrosio, la intolerancia y el fanatismo de las monjas de Santa Clara, capaces de condenar a muerte atroz a quienes optan por seguir el dictado de la naturaleza, y, sobre todo, la ambición del monje y su lujuria, que llega a asesinar a Elvira, su propia madre, y a violar a su hermana Antonia para satisfacer su incontinencia sexual.

Aunque Radcliffe, por su parte, no alcanza las cotas de Lewis, también ambienta una parte de su novela en el convento de San Esteban, donde la candidez de Ellena se enfrenta a la malignidad envidiosa de las monjas y la soberbia e injusticia de su superiora. Reaparece aquí el tema de las vocaciones forzadas, así como la cuestión de la hipocresía e inhumanidad de ciertos conventos católicos, que, aliados con el poder, han relegado sus auténticos deberes cristianos. En las dos novelas inglesas, la Inquisición toma un papel fundamental en el desenlace del relato, y aunque ejerce en ellas el papel de supervisora y garante del orden en el seno de la Iglesia persiguiendo y torturando a los monjes corruptos-, se desvelan sin ambages sus crueles procedimientos y sus reglas injustas y obsoletas, despóticas como los regímenes que las auspician. Al final de los relatos, la Inquisición desvela su propia ineficacia para restaurar el orden perdido: Ambrosio se esfuma de sus calabozos con la oportuna ayuda de Lucifer, mientras que el pérfido Schedoni se envenena, asesinando de paso también a su cómplice y privando al Santo Oficio de la oportunidad de exponer públicamente la fuerza de su poderoso brazo.

2) Los villanos de estas novelas, aquellos que amenazan con sus intrigas el bienestar individual y la felicidad social, son en su mayor parte clérigos regulares, monjes y religiosas, que ostentan un cierto poder. Consideradas en conjunto, las tres obras constituyen un muestrario sin parangón de perversiones monásticas de toda índole, encabezadas por abadesas enloquecidas, crueles, fanáticas y libidinosas, y por frailes corruptos, taimados, lujuriosos y desprovistos de auténtica vocación religiosa. Exceptuando quizá a la abadesa de Saint-Eutrope en La religiosa, que nos deleita con unas crisis de ardor lésbico únicas en la narrativa española de su tiempo, Ambrosio y Schedoni son, posiblemente, los más impactantes; el primero como 
reinterpretación del héoe rousseauniano, el individuo naturalmente bueno, pero corrompido y alienado de su auténtico yo por la hipocresía de la educación religiosa. De santo a villano gótico gracias a su paso por el monasterio, el fraile es capaz de casi cualquier aberración que le garantice la satisfacción de sus deseos, hasta de renunciar a su fe y abdicar de los principios de la religión católica para evitar los tormentos inquisitoriales. En contraste con la nefasta influencia que el medio parece tener en la conducta de Ambrosio, los atropellos del padre Schedoni en El confesonario de los Penitentes Negros ni tan siquiera encuentran justificación en las desviaciones causadas por la reclusión monástica, sino que son la ambición y las aspiraciones de poder del dominico las que lo empujan a mentir, engañar, raptar y asesinar.

3) No deja de ser curioso que, pese a todo lo señalado, estas novelas no puedan considerarse antirreligiosas, en la medida en que ninguna de ella atenta frontalmente contra los dogmas fundamentales del catolicismo. No lo hace, desde luego, La Religieuse, cuya heroína, Suzanne Simonin, mantiene incólume su fe hasta el final, y gracias a ella - y al apoyo de los sacerdotes con los que se topa, que son en su mayoría bondadosos, inteligentes y caritativos- logra enfrentarse a las adversidades que debe afrontar en su particular Via Crucis por diferentes conventos parisinos. Tampoco lo hace Ann Radcliffe en The Italian, que opone al horror del convento de San Esteban y a la maldad de Schedoni, Nicolás de Zampari y otros clérigos de semejante ralea, el paraíso de paz y felicidad del Convento de la Piedad, poblado por monjas sensibles, inocentes, caritativas y virtuosas, como demostración de que el retiro voluntario del mundanal ruido no genera monstruos cuando lo inspira la auténtica fe. Como Suzanne Simonin, Ellena di Rosalba mantiene su devoción y confianza en la voluntad divina hasta el final, y mientras a los monjes corruptos les espera una muerte atroz (causada, por cierto, por ellos mismos), la heroína virtuosa recibe su recompensa.

Aunque ninguna de las dos novelas ataca directamente la fe católica - de hecho La Religieuse, que es la más implacable de las dos, ni siquiera estuvo en el Índice inquisitorial francés de $1804^{34}$-, es lógico pensar que la crudeza con la que muestran la imperfección de sus instituciones las hacía susceptibles de convertirse en textos non gratos para la Iglesia española. Mucho más todavía The Monk, cuya ambigüedad moral, especialmente en sus últimas páginas, había alertado a los propios críticos británicos, quienes temían que la humanidad del padre Ambrosio,

\footnotetext{
${ }^{34}$ A diferencia de las obras de Voltaire, que figuran en bloque en dicho Índice galo, sólo una obra de Diderot se añade en 1804, Jaques le fataliste, que había aparecido -por cierto- al mismo tiempo que La Religieuse. Si tenemos en cuenta que, de las dos obras anteriores, Jacques le fataliste era precisamente la que había obtenido menor repercusión entre la crítica y el público lector, el silencio del Índice francés sobre La Religieuse nos indica que su contenido no la hacía aparecer, a diferencia de la otra, como un texto hostil a la religión establecida o peligroso para la fe.
} 
que lo lleva incluso a renunciar a su fe, suscitara la afinidad o la simpatía de los lectores. Recordemos que, tras ser condenado por el Santo Oficio a morir en la hoguera por su comportamiento aberrante y sus prácticas satánicas, Ambrosio logra evadirse del castigo inquisitorial para caer en las garras de Lucifer. Es tentado por el diablo, que le exige su alma a cambio de escapar de las agonías de una muerte terrible. A pesar de sus dudas al respecto, la idea de la salvación en el más allá no parece compensar el sufrimiento terrenal que se anuncia, y el monje opta finalmente por otorgar su confianza al diablo. Obviamente, este lo engaña, y una vez lo ha hecho suyo, lo despeña y lo somete a siete días de agonía, en los cuales Ambrosio muere devorado por los buitres y arrastrado por una corriente de agua hacia el mar.

Cierto es que tanto las continuas violaciones de la regla monacal y de los fundamentos cristianos como el debilitamiento final de la fe de Ambrosio, al renunciar al dogma de la vida eterna para disfrutar más tiempo de las mieles de la terrena, reciben el castigo merecido, con lo cual la obra resulta, desde el punto de vista de su ejemplaridad religiosa, intachable. Pero también es verdad que, para llegar hasta ese final preventivo y ejemplarizante, la novela se sitúa peligrosamente en los márgenes de la moral y de la ortodoxia cristianas, mostrando un siniestro sentido del terror religioso que algunos críticos han relacionado con el profundo fondo calvinista del texto de Lewis ${ }^{35}$; de hecho, no se advierte en él presencia divina alguna, ni los personajes parecen estar especialmente inspirados o protegidos por la bondad suprema, ausente de toda la obra. Todo lo contrario, sus auténticos protagonistas son Lucifer, que se muestra una y otra vez bajo apariencias diversas, los rituales satánicos y las estrategias de Ambrosio para burlar la justicia humana mediante pactos oscuros. Desde luego, la fe no triunfa, ni en el caso de la virtuosa Elvira, que muere asfixiada por el mismo hijo al que le arrebataron de niña (el propio Ambrosio), ni en el de Antonia, cuya devoción y religiosidad no le impiden ser víctima de envenenamiento, estupro y asesinato, ni en el de la monja Inés, cuyo hijo ilegítimo recién nacido muere de frío y de inanición en los subterráneos del convento, ni mucho menos en el de Ambrosio, quien, como hemos señalado, después de incurrir en el máximo delito contra la fe (la apostasía), no es víctima como debería- de la justicia humana ni de la divina, sino de la del mismo Lucifer,

\footnotetext{
${ }^{35}$ El crítico norteamericano J. Porte, por ejemplo, interpreta la ficción gótica como máxima expresión de la inquietud religiosa protestante. De esta forma, aunque la acción se traslada generalmente a escenarios católicos, el drama que se desarrolla en ellas es, según Porte, netamente luterano y tiene que ver con los oscuros ritos del pecado, la culpa y la condenación. En esta misma clave analiza Porte la novela de Lewis, que interpreta como una alegoría calvinista sobre el pecado original y la pérdida de la gracia divina, y como una más de las numerosas manifestaciones literarias de la angustia presbiteriana acerca de la vida eterna y de la condenación sin posibilidad de redención con las que nos deleita la narrativa anglosajona a lo largo de los siglos XVIII y XIX (1974, pp. 42-64).
} 
que gana la partida a las fuerzas del bien e impone, en un desenlace absolutamente magistral de Lewis, sus demoníacos designios.

Parece claro, en resumen, que la ofensiva anticlerical que encontramos en estas tres obras, recrudecida en el caso de The Monk por sus ambiguos equilibrios en el asunto de la ortodoxia religiosa, las convertía en textos inapropiados para recibir el beneplácito de las rígidas instancias eclesiásticas españolas. Si tenemos en cuenta, además, que en las tres obras el tratamiento de la materia clerical se acompaña de una lectura política más o menos explícita, entenderemos aún mejor la proyección ideológica que tales textos podrían haber alcanzado en la España borbónica y las razones por las que no aparecieron en ella.

No en vano las tres son, aunque desde diferentes perspectivas, reelaboraciones de un mismo tema: la desprotección del individuo frente a una sociedad materialista, hipócrita y ruin, dominada por ciertas instituciones represoras -la Iglesia y la Inquisición, claro, pero también las clases altas y en última instancia el Estado- caracterizadas por el anquilosamiento ideológico, la ambición económica y el ansia de poder, que refrendan su estrategia de control social coartando la libertad personal -amorosa, sexual, vital en suma- de los otros. Las tres se recrean en la descripción de un paisaje social corrupto, compuesto de verdugos y víctimas, en el que los primeros pertenecen a los núcleos que ostentan el poder moral y/o material (clero, inquisidores, nobleza y alta burguesía) y las segundas -que generalmente son mujeres privadas del amparo familiar- luchan denodadamente por no claudicar y por rescatar su integridad física y moral del acoso de aquellos. En los tres textos, el cuerpo femenino perseguido, mancillado, vejado y violentado se presenta como símbolo de la debilidad del cuerpo social ante quienes imponen el orden espiritual y material, y también en los tres la opresión de las víctimas por altos cargos de la jerarquía eclesiástica visibiliza una alianza más o menos explícita entre clerecía y poder, propia de un régimen obsoleto, que solo causa destrucción y horror .

El enclaustramiento de Suzanne Simonin contra su voluntad tiene, por ejemplo, una motivación económica y social, ya que su condición de hija natural la convierte en un lastre moral para su madre y en un apéndice incómodo para la distribución familiar de la herencia. Su oportuno ingreso en el convento, impuesto por los padres con el beneplácito de la institución religiosa, viene a resolver un conflicto de lo más mundano, contribuyendo a mantener el orden burgués del honor y del dinero a través de la violencia ejercida contra el más débil. Todo ello, claro está, bajo el amparo de la autoridad civil, del Estado y del Rey, quienes hacen oídos sordos a las protestas de las víctimas para no vulnerar el estatus. De hecho, recordemos que es ante una autoridad civil, un tribunal compuesto de magistrados y no de clérigos, ante el que pleitea el abogado de Suzanne Simonin, Mr. Manouri, a quien la Iglesia ha autorizado previamente a llevar adelante el proceso. Es obvio que el mensaje antimonástico de Manouri -y de Diderot- se dirige fundamentalmente al Estado, no a la Iglesia. 
Fue posiblemente por esa razón por la que La Religieuse, que, como hemos señalado, escapó en Francia a la censura de Roma, fue prohibida en dos ocasiones en tiempos de la Restauración, en 1824 y en 1826, demostrando que constituía una amenaza más grave para el poder temporal de los Borbones que para la autoridad espiritual de los Papas. La novela de Diderot fue proscrita por un gobierno que veía en ella un mensaje sedicioso capaz de amenazar la base misma de su existencia: la institución conventual representa un orden caduco, un peligro moral y social, que un gobierno razonable y preocupado por el bienestar de sus ciudadanos debería suprimir, o, al menos, controlar rigurosamente. Si el gobierno de Charles X, sólidamente apoyado en la Iglesia, supo leer perfectamente el mensaje y prohibió sin demora una obra que lo instaba a actuar contra la institución monástica y a privarse en consecuencia de su más firme sostén, ¿no habría actuado de forma similar la monarquía española de Carlos IV o de Fernando VII si la novela hubiese tratado de traducirse en nuestro país durante sus reinados? De hecho, la versión española, que se publicó en París antes de la prohibición (en 1821), no llegó a imprimirse en territorio español ni siquiera durante el Trienio.

Los oscuros pactos entre el poder y la Iglesia en virtud de intereses comunes se encuentran también presentes en las dos novelas inglesas que estudiamos, las cuales plantean, como La Religiosa, el asunto de las vocaciones forzadas, instigadas por familias poderosas que encuentran el apoyo de superioras crueles y fanáticas. El hecho de que algunos representantes de las instituciones religiosas constituyan en estas novelas un peligro físico y espiritual para sus semejantes era, evidentemente, razón suficiente para que no vieran la luz en España, pero el que las tropelías del clero se realicen con la protección, la connivencia o la indiferencia de quienes encarnan el orden social y moral establecido -el viejo orden de cosas- las convertía a ojos del establishment borbónico en lecturas no sólo desaconsejables sino incluso potencialmente sediciosas.

De hecho, la caída y perdición de Antonia en El fraile tienen lugar porque quienes deberían haberla protegido - la nobleza, clase social a la que pertenece por origen- la abandonan a su suerte. Antonia, que es nieta de un conde pero también de un humilde zapatero, fue privada desde su nacimiento de los derechos de linaje y de herencia que le correspondían, que no consigue recuperar, por avatares del destino, en toda la novela. Así, la joven se convierte en víctima por partida doble: de los prejuicios de clase de los que tienen su propia sangre, por un lado, los cuales, al ignorarla, la ponen a merced de Ambrosio, y de la lujuria de un fraile experto en ocultar su verdadera naturaleza, por el otro.

En el caso de El confesonario de los penitentes negros, el pacto entre el padre Schedoni y la Marquesa - madre del protagonista y enamorado de Ellena, Vivaldipara evitar el matrimonio de los jóvenes, permite aún más claramente ligar la corrupción de ciertas instituciones católicas con la del sistema monárquico-feudal. De hecho, ambos personajes representan distintas facetas del antiguo régimen y defienden sus valores, fundados en los derechos del privilegio. La Marquesa, con 
sus acciones y su discurso, ratifica el deseo de un mundo medieval, de rígidas jerarquías y soberanía absolutamente feudal. Schedoni, por su parte, movido por intereses bastardos, apoya las pretensiones de la Marquesa, pero al mismo tiempo introduce en la novela el relativismo moral, con un discurso de libertinaje filosófico reminiscente del de los librepensadores blasfemos del Marqués De Sade. El oscuro confesor defiende la moral natural, dejando entrever que costumbre y ley no son más que vulgares prejuicios, y afirmando un mundo moralmente anárquico, de autoaserción y poder.

El pacto de ambos personajes revela de forma bastante obvia que, en la reconstrucción hecha por Radcliffe del pasado continental, libertinaje filosófico y antiguo régimen forman una alianza cuya inmoralidad aparece ligada a la inestabilidad social del presente. Por otra parte, frente a la exigencia de los derechos del privilegio encarnada por Schedoni y la Marquesa, El confesonario afirma taxativamente la inviolabilidad de los derechos humanos a través de la pareja opuesta, la que forman los inteligentes, virtuosos y sensibles Ellena y Vivaldi. Los dos representan en la novela la fuerza de una clase media -entre la corrupción aristocrático-clerical de la Marquesa o Schedoni y el estrato ocupado por criados y campesinos-, cuya condición fundamental es la sensibilidad, a través de la cual se expresan como seres humanos. La novela refleja, en este sentido, las tensiones sociales de la Inglaterra del momento, entre una burguesía liberal, que enarbolaba unas nuevas nociones de moralidad y propiedad, y una vieja élite, percibida como lujuriosa, superficial, inmoral y retrógrada; Ellena di Rosalba y su madre, Olivia, despojadas de sus derechos básicos por esa aristocracia recalcitrante, son el mejor ejemplo de dichas tensiones y de los peligros inherentes. A tenor de todo esto, que The Italian no viera la luz en España durante todo el período de férrea defensa de la ideología absolutista y sus valores, es decir, en tiempos de los Borbones, no puede sorprender a nadie.

Aún más significativo es el caso de The Monk, que no solo permanece alejada del ámbito español hasta 1822, sino que, cuando al fin aparece en nuestro idioma, lo hace en una versión notablemente depurada, lo cual apunta a que su contenido podía resultar arriesgado hasta en período liberal. Así, El fraile apareció en la España del Trienio en una versión que conserva las escenas de mayor erotismo y voluptuosidad, las violaciones, parricidios y asesinatos del clérigo protagonista, pero que sorprendentemente -o quizá no tanto- obvia casi por completo la segunda trama del texto original de Lewis. De hecho, la extensa y sustanciosa historia de Agnes (Inés de Medina, en español), obligada por supersticiones familiares a tomar el velo, y de Ramón, Marqués de las Cisternas, que abarca en la novela inglesa cuatro capítulos completos (capítulo III del volumen I, I y II del vol. II, y III del volumen III) y aproximadamente la mitad de otros dos (capítulos I y IV del vol. III), queda tan drásticamente reducida en la versión española que los tres volúmenes del texto original publicado por Bell en 1796 se convierten en uno solo en la edición madrileña de 1822 . 
Recordemos que la obra de Lewis alterna la narración de los desmanes pasionales de Ambrosio con la de la historia de amor de Inés y Ramón de las Cisternas, haciendo confluir los dos relatos al final de la novela e intercalando en ellos -especialmente en el segundo- otras historias directa o indirectamente relacionadas, que contribuyen a configurar esa compleja estructura narrativa que constituye esta novela. La segunda línea argumental incluye la relación detallada de los inicios de la relación de Inés y Ramón en el castillo alemán de Lindenberg, que la joven se ve obligada abandonar precipitadamente debido a los celos de su tía, la Baronesa, para ingresar en el convento madrileño de Santa Clara, al que estaba destinada desde niña; incluye también el relato de las aventuras de Ramón con los villanos de los bosques de Estrasburgo y la historia de la "monja ensangrentada» («bleeding nun») que acosa a los habitantes del castillo de Lindenberg. Las dos tramas de la novela confluyen por vez primera cuando Ambrosio descubre por azar los planes de Inés, que espera un hijo de Ramón, para huir del convento, y la descubre ante la abadesa. Las religiosas de Santa Clara, alentadas por el fanatismo de su superiora, urden una conspiración para hacer desaparecer a Inés y al fruto de su pecado en los subterráneos del convento, y la hacen pasar por muerta ante su familia. Finalmente, la oportuna intervención de Lorenzo de Medina, hermano de Inés, al revelar públicamente las ignominias cometidas intramuros con total impunidad, da pie a una rebelión popular que le facilita el acceso a los subterráneos, donde consigue rescatar in extremis a la joven, aunque no a su hijo. Los dos núcleos argumentales se cruzan de nuevo en este punto, cuando Lorenzo encuentra casualmente en los subterráneos a Antonia, violada y herida de muerte por Ambrosio, y consigue detener al fraile y a su instigadora, la demoníaca Matilde.

Las referencias en la versión española a la historia de Inés de Medina, que, como vemos, ocupa una parte considerable de la novela original, se limitan a la sucinta narración, en el capítulo II, del desafortunado encuentro entre Ambrosio e Inés (episodio conservado en la traducción como muestra de la hipocresía y la inflexibilidad del dominico al revelar el secreto de la joven condenándola a un futuro incierto $)^{36}$, y a unas cuantas líneas en el capítulo III, en las que la abadesa anuncia a Sor Camila el triste destino que espera a Inés de Medina ${ }^{37}$. De hecho, la omisión de todo lo sucedido a Inés en los subterráneos de Santa Clara produce considerable confusión en el desenlace de la versión española, ya que, aunque Matilde informa a Ambrosio de la revuelta popular contra el convento, no se comprenden las razones de la misma, ni tampoco se explica cómo ni por qué aparece Lorezo de Medina en los subterráneos acompañado de los alguaciles de la Inquisición. De igual modo, la versión española da cuenta de la enfermedad de Ramón de las Cisternas debida a su certeza sobre el fallecimiento de Inés, aunque lo

\footnotetext{
${ }^{36}$ Lewis (1822), pp. 61-70.

${ }^{37}$ Lewis (1822), pp. 145-146.
} 
cierto es que anteriormente no se ha hecho referencia ninguna en el texto a esta supuesta muerte ${ }^{38}$.

¿Qué razones llevaron al traductor a deshacerse de este modo de la sustanciosa historia de Inés y Ramón, aun a riesgo de perjudicar la coherencia interna de la trama? Al fin y al cabo, esta segunda línea argumental ofrecía ingredientes atractivos para una novela de entretenimiento, como lo sentimental (la historia de amor más allá de códigos sociales, la muchacha víctima de la opresión familiar...), lo terrorífico (el relato de la «monja ensangrentada» que se cuenta en el castillo de Lindenberg), la aventura (las andanzas de Ramón de las Cisternas en Alemania, el episodio en los subterráneos del convento, etc.) o el final feliz (Inés y Ramón reunidos en las últimas páginas de la novela). Es posible, desde luego, que el traductor optara sencillamente por simplificar la complejidad narrativa que caracteriza el texto original eliminando la trama «subsidiaria» y unificando los tres volúmenes en uno solo, lo cual, a su vez, abarataría notablemente los costes de la edición. No obstante, si analizamos el contenido de algunos de los capítulos omitidos, no es difícil intuir la existencia de otras razones, que posiblemente vienen a sumarse a las anteriores, para explicar la opción traductora de reducir sustancialmente el original de Lewis.

El punto culminante de la historia de Inés y Ramón se encuentra en el capítulo III y en la primera parte del capítulo IV del volumen III del texto de Lewis. En ellos, Lorenzo de Medina, que ha conseguido una orden de detención contra la abadesa del convento, acude a la procesión en honor de Santa Clara dispuesto a desenmascarar a aquélla y recuperar a su hermana Inés, supuestamente muerta. Lorenzo encarna aquí al héroe racional y civilizado, antítesis ilustrada de Ambrosio, que se aproxima a la Iglesia haciendo gala de espíritu revolucionario, dispuesto a liberar a sus compatriotas de los «grilletes monacales» y a revelar la verdad oculta tras las rejas de las instituciones eclesiásticas, «exponer sin ambages a la gente cuán enormes eran los abusos que con tanta frecuencia cometíanse en los monasterios, y cuán injusta e indiscriminadamente concedíase la estima pública a cuantos llevasen un hábito religioso» ${ }^{39}$. Cuenta para ello con el testimonio de una de las religiosas del convento, quien se enfrenta a la abadesa públicamente, y a través de la narración de los horrores perpetrados contra Inés por aquella y por sus propias compañeras, revela la arbitrariedad con la que actúan las instituciones monásticas, así como la ausencia de cualquier control civil sobre ellas. La sensación de impotencia que sus declaraciones generan en la multitud asistente a la procesión provoca una reacción popular de tal magnitud que culmina con el asesinato de la abadesa, el asalto e incendio del convento y la huida de las monjas. Inés es finalmente rescatada por su hermano, y aunque su estado físico y mental es deplorable tras el prolongado

\footnotetext{
${ }^{38}$ Lewis (1822), p. 239.

${ }^{39}$ Cito de la traducción actual de J.A. Molina Foix (El monje, 2003, p. 452).
} 
encierro en los sótanos del convento, consigue recuperarse y hacer una narración detallada -y sobrecogedora- de las penalidades sufridas.

Aunque cuando la novela se recibió en Inglaterra, los episodios con contenido sexual y los desmanes pasionales de Ambrosio atrajeron especialmente la atención de los moralistas, lo cierto es que la historia de Inés de Medina no le queda a la zaga, e incluso me atrevería a afirmar que el contenido de estos dos capítulos del volumen III resulta aún más impactante, morboso y subversivo que las andanzas del fraile, hasta tal punto que se omitió por completo en la versión española.

Desde luego, de poca ejemplaridad gozarían, a ojos de esa España liberal que lidiaba a duras penas con el anticlericalismo radical de sus sectores más exaltados, lo explícito de la narración de las maldades conventuales, perpetradas sin freno ni control, el asesinato de la abadesa por la multitud, las escenas de violencia subsiguientes $^{40}$, que culminan en el asalto e incendio del convento por la multitud enfurecida -eco aún del impacto que los sucesos revolucionarios franceses había causado al otro lado del canal ${ }^{41}$ - y la ausencia manifiesta de intervención de la autoridad civil en toda esta barbarie. Tal como hemos señalado al principio de este trabajo, y como consecuencia de la implicación de la mayoría del clero en la defensa del absolutismo, entre 1821 y 1823 se produjeron en España ciertas

40 «Los alborotadores [...] negáronse a escucharla: prodigáronle toda clase de insultos, cubriéronla de barro e inmundicia y la motejaron con los más oprobiosos apelativos. [...] Con sus aullidos y execraciones ahogaban los estridentes gritos de piedad de la monja y arrastrábanla por las calles, dándole patadas, pisoteándola y sometiéndola a toda clase de crueldades que el odio o la furia vindicativa podía inventar. Finalmente, una piedra lanzada por alguna mano diestra, diole de lleno en la sien. Desplomóse al suelo bañada en sangre y en pocos minutos se acabó su miserbale existencia. Sin embargo, aunque ya no sentía sus insultos, los alborotadores continuaron descargando su rabia e impotencia sobre su cuerpo sin vida. Golpeáronlo, pateáronlo y maltratáronlo, hasta que no fue más que una masa de carne informe, desagradable a la vista y repulsiva.

[...] Entretanto, el populacho asediaba el edificio con perseverante rabia: derribaban sus muros, arrojaban por las ventanas antorchas encendidas y juraban que cuando despuntase el día ninguna monja de la orden de Santa Clara quedaría con vida. [...] El convento, envuelto en llamas, ofrecía todo un espectáculo de devastación y horror» (Ibídem, pp. 461-2).

${ }^{41}$ No se escapan, desde la publicación del concienzudo trabajo ya citado de Maurice Lévy, las conexiones entre el «Terror político», particularmente el francés, y las novelas góticas, que, por otro lado, ya habían sido puestas de manifiesto en su tiempo por perspicaces observadores como el propio Marqués de Sade. Como explica Lévy, las novelas góticas escritas a partir de la década de 1790, no son una mera transcripción de los horrores revolucionarios, sino más bien una expresión de la angustia provocada por ellos. Por lo que respecta al contexto inglés, Lévy asocia esta angustia con los levantamientos políticos, religiosos e intelectuales de 1688 y posteriores, aquella «revolución gloriosa» que legó al siglo XVIII el racionalismo científico y la reforma religiosa. (Ver el capítulo X, «Estructuras profundas» del citado texto de Lévy). 
acciones populares violentas contra clérigos conocidos, iglesias y monasterios ${ }^{42}$, algunas de una brutalidad excepcional. Las páginas de Lewis a las que hacemos referencia, escritas cinco lustros antes de los acontecimientos del Trienio, parecen casi una premonición de ese espíritu de rebelión anticlerical con el que se inicia la tercera década del XIX en nuestro país. No sería de extrañar que cuando la novela se tradujo en 1822, las muestras de furia popular contra las monjas de Santa Clara en el capítulo III se consideraran una incitación a la violencia anticlerical que en nada beneficiaba la estabilidad política del período $y$, por ende, se suprimieran sin contemplaciones.

Lo mismo ocurrió seguramente con la narración que hace Inés de su castigo en los subterráneos del convento a lo largo del capítulo IV. Por decisión de su superiora y con la connivencia de las otras religiosas, la monja es torturada, condenada a ser encerrada de por vida en un subterráneo inmundo y pestilente, a dar a luz en solitario y a enfrentarse a una consunción paulatina y terrible, por frío e inanición. La relación de la tortura de Inés es absolutamente impactante, insistiendo especialmente en los detalles más escabrosos, como la imagen de la monja enloquecida acunando el cadáver putrefacto del recién nacido, en un último intento de conservar un vínculo con la vida que se escapa:

Rasgué mi mortaja y envolví en ella a mi lindo niño. Lo coloqué sobre mi pecho, con su suave bracito rodeándome el cuello y su pálida y helada mejilla contra la mía. [...] Convirtióse pronto en una masa putrefacta, repugnante y asquerosa a los ojos de cualquiera, salvo a los de su madre [...]. En vano impulsábanme los sentimientos humanos a retroceder con repugnancia ante este emblema de mortalidad. Resistí y vencí esa repugnancia. Seguí conservando a mi hijito conmigo, llorándole, queriéndole, jadorándole!. Pasaba hora tras hora en mi lamentable lecho, contemplando lo que antes había sido mi hijo. Esforzábame en reconstruir sus facciones bajo aquella lívida corrupción que las cubría [...] A menudo, al despertarme, encontraba anillados a mis dedos los largos gusanos que criábanse en la carne putrefacta de mi niño ${ }^{43}$.

42 En 1821, el cura de Tamajón, Matías Vinuesa, es brutalmente asesinado, y al año siguiente lo es el obispo de Vich, Strauch. En ambos casos se trató de acciones colectivas, aparentemente sin un plan previo elaborado. En general, en el bienio 1822-1823 murieron violentamente 95 religiosos y sacerdotes. La mayoría de estos asesinatos se produjo en Cataluña, demostrando un considerable ensañamiento contra los clérigos: uno de los milicianos que participó en la muerte del franciscano Luis Pujol mojó una rebanada de pan en su sangre aún caliente, al cura de Santa Inés le sacaron los ojos, le retorcieron los dedos hasta arrancárselos y le acuchillaron la tonsura, al vicario de Vilafortuny lo apuñalaron y todavía vivo lo tiraron a un pozo, etc. Tomo los datos de Emilio La Parra (2000), p. 256; (1998), pp. 58-61.

${ }^{43}$ Lewis, trad. J.A. Molina Foix, pp. 513-514. 
Probablemente, los sucesos de Santa Clara fueron eliminados de la versión española porque convertían la aparente excepcionalidad del comportamiento aberrante de Ambrosio en una característica general de la vida monástica, capaz de ocultar todo un rosario de perversiones e intereses mezquinos, y también porque insinuaban veladamente que la incapacidad del poder civil para hacer frente a unas prácticas establecidas secularmente solo podía resolverse mediante la sublevación popular. La terrible historia de Santa Clara podía, por la crudeza de los hechos y por lo explícito de sus consecuencias, alentar la animadversión -más aún, la rebeliónde ciertos sectores populares españoles contra la Iglesia, lo cual quedaba lejos de los intereses del bando liberal, que hacía esfuerzos ímprobos por ganarse al clero, mostrando a toda costa sus actuaciones positivas ${ }^{44}$. La recepción en nuestro país del texto de Lewis resulta, pues, especialmente compleja por sus implicaciones ideológicas, de forma que ni siquiera en el período constitucional consigue el texto llegar íntegro a los lectores españoles ${ }^{45}$.

Recapitulando lo expuesto hasta el momento, hallamos que entre 1821 y 1822 , es decir, durante el Trienio Liberal, se traducen al español tres novelas de contenido anticlerical del ámbito europeo, dos inglesas y una francesa, publicadas en el último lustro del XVIII: The Monk, The Italian y La Religieuse. Hemos señalado en los tres textos una coincidencia de rasgos temáticos y formales, propios de las tendencias de la narrativa europea de su tiempo, tales como la explotación de recursos de la novela gótica, la tendencia a lo sentimental o la explotación del tema de la inocencia perseguida, entre otros. Pero además, hemos comprobado que los tres comparten la presencia de una marcada retórica anticlerical, que conduce a una crítica de la naturaleza coercitiva y opresora de las instituciones eclesiásticas y de otras afines -nobleza, Estado- así como a la revelación de la ineficacia de todas ellas para garantizar la libertad y la felicidad de los individuos. Este mensaje, en clara sintonía con el individualismo europeo decimonónico y con el concepto de sensibilidad que impregna las manifestaciones culturales de entresiglos, tenía no obstante difícil cabida en los estrechos márgenes ideológicos del absolutismo español, sostenido precisamente sobre los cimientos de las mismas instituciones que estas novelas ponen en tela de juicio, lo cual las convierte en textos non gratos -y por tanto ausentes- en el panorama literario español bajo el régimen borbónico. El hecho de que se traduzcan a nuestro idioma por vez primera en los años del Trienio, como resultado de las novedades legislativas en materia de libertad de imprenta, da cuenta del interés de los lectores españoles de novelas por la materia anticlerical, difícilmente perceptible atendiendo tan solo a las escasísimas obras originales que presentan este motivo a lo largo del primer tercio del siglo XIX. Solo a partir de

\footnotetext{
${ }^{44}$ La Parra (1998), p. 58.

45 De hecho, la primera traducción completa, incluyendo todos los episodios de Santa Clara, que he podido consultar, es la de León Compte (Barcelona, Juan Pons, 1877).
} 
1832, tras la muerte de Fernando VII, se retoma una narrativa de fondo anticlerical que da lugar a relatos seudohistóricos como El golpe en vago (1834) de José García de Villalta o El auto de fe (1837) de Eugenio de Ochoa, y algo más tarde, en las décadas de los cuarenta y cincuenta, a novelas poco conocidas de corte aventurero y folletinesco, como las de Francisco Roballo (La criolla y los jesuitas), José Pastor de la Roca (La cruz y la calavera o los subterráneos de la Inquisición) o Joaquín María Nin (Secretos de la Inquisición. Novela histórica). Muy poco queda ya, desde luego, en estos últimos textos, de la vigorosa originalidad de las novelas de Lewis, Radcliffe, Diderot, Gutiérrez o Blanco White, de su fascinante poder de transgresión, de su interés por investigar en los claroscuros del alma humana y, sobre todo, de su desafiante voluntad, impregnada de sensibilidad dieciochesca y de espíritu romántico, de revelar la indefensión y la soledad del individuo ante las convenciones del sistema, de la Iglesia, de la sociedad y de la ley. Bastante más, desde luego, de su anticlericalismo manifiesto sustentado en una aparente ortodoxia religiosa, encontramos en algunos de nuestros románticos más radicales (Fígaro, Espronceda) y moderados (Gil y Zárate, Hartzenbusch, etc.). Un estudio riguroso de los lazos e influencias entre el anticlericalismo romántico español y la recepción en España de la literatura europea de su tiempo, queda aún pendiente.

\section{Obras citadas}

BLANCO White, José María: Vargas, novela española, trad. y ed. de Rubén Benítez y María Elena Francés, Alicante, Instituto de Cultura Juan Gil-Albert, 1995.

CALDERA, Ermanno: «L'Inquisizione e il fanatismo religioso nel teatro spagnolo del primo Ottocento», Letterature, 8 (1985), pp. 27-42.

CALDERA, Ermanno: «Il teatro del pathos e dell'orrore al principio dell'ottocento: fedeltà ai canoni del classicismo e presentimenti romantici», Entresiglos, I (1991), pp. 57-75.

CARNERO, Guillermo: «Sensibilidad, terror y medievalismo en la narrativa del siglo XVIII», en La cara oscura del Siglo de las Luces, Madrid, Cátedra, 1983, pp. 95-123.

CARNERO, Guillermo: «La Holandesa de Gaspar Zavala y Zamora y la literatura gótica del XVIII español», en Homenaje al profesor José Fradejas Lebrero, II, coords. J. Romera, A. Freire y A. Lorente, Madrid, UNED, 1993, pp. 517-539.

CARO BAROJA, Julio: Introducción a una historia del anticlericalismo español, Madrid, Istmo, 1980.

COLERIDGe, Samuel T.: «The blasphemy of The Monk», Critical Review, 1796, pp. 198-200.

CORTÉS PEÑA, Antonio Luis: La política religiosa de Carlos III y las órdenes mendicantes, Granada, Servicio de Publicaciones, 1989.

DALE, Scott: «Luis Gutiérrez y la epistolaridad escandalosa en Cornelia Bororquia», Salina, 18 (2004), pp. 127-132. 
DE CuENCA, Luis Alberto: «Introducción» a Agustín Pérez Zaragoza, Galería Fúnebre de Espectros y Sombras Ensangrentadas, Madrid, Editora Nacional, 1977.

DE CuENCA, Luis Alberto: «La literatura fantástica española del siglo XVIII», Cuadernos Hispanoamericanos, 410 (1984), pp. 107-118.

DE LA CueVA Merino, Julio: «El anticlericalismo en España. Un balance historiográfico», en Benoît Pellistrandi (éd.), L'histoire religieuse en France et en Espagne, Collection de la Casa de Velázquez, 87, Madrid, 2004.

DIDEROT, Denis: La religiosa, Paris, Rosa, 1821.

FERRERAS, Juan Ignacio: Los orígenes de la novela decimonónica (1800-1830), Madrid, Taurus, 1973.

FLEENOR, Juliann: The Female Gothic, Montréal; London, Eden Press Inc., 1983.

GARCÍA CASTAÑEDA, Salvador: «El pan amargo del destierro. Letras y exilio en el período fernandino», Monographic Review/Revista Monográfica, II (1986), pp. 20-34.

GARCÍA CASTAÑEDA, Salvador: «La Inquisición, tema literario en la novela de la emigración (1800-1837)», 1987, Biblioteca Virtual Miguel de Cervantes, http://www.cervantesvirtual.com/servlet/SirveObras/1215940977810375297684 6/p0000001.htm\#I_0, consultado el 29/07/2009.

GARNICA, Antonio: "La novela anticlerical española. Estudio comparativo de Cornelia Bororquia y Vargas», Exemplaria, 1 (1997), pp. 75-96.

GLENDINNING, Nigel: «Lo gótico, lo funeral y lo macabro en la cultura española y europea del siglo XVIII», Anales de Literatura Española, 10 (1994), pp. 101115.

GuTIÉRrez, Luis: Cornelia Bororquia o la víctima de la Inquisición, ed. de Gérard Dufour, Alicante, Instituto Juan Gil-Albert, 1987.

LA PARRA, Emilio: La libertad de prensa en las Cortes de Cádiz, NAU, Valencia, 1984.

LA PARRA, Emilio: «Los inicios del anticlericalismo español contemporáneo (17501833)», en Emilio La Parra y Adolfo Suárez Cortina (eds.), El anticlericalismo español contemporáneo, Madrid, Biblioteca Nueva, 1998, pp. 17-68.

LA PARRA, Emilio: «El anticlericalismo durante el Trienio Liberal», en Scripta in honorem Enrique A. Llobregat Conesa, coords. Manuel Olcina y Jorge A. Soler, vol. II, Alicante, Instituto Juan Gil Albert, 2000, pp. 245-262.

LEVY, Maurice: Le Roman 'gothique' anglais 1764-1824, Toulouse, Faculté des Lettres et Sciences Humaines, 1968.

LEWIS, Matthew G: «El fraile ó historia del padre Ambrosio y de la bella Antonia», Madrid, 1822.

LEWIS, Matthew G.: El monje, ed. de Juan A. Molina Foix, Madrid, Cátedra, 2003.

MALIN, Mark R.: «The Truth of Power and the Power of Truth: Luis Gutiérrez'Cornelia Bororquia», Dieciocho, vol. 25, 1 (2002), pp. 7-24. 
MAY, Georges: Diderot et «La Religieuse». Étude historique et littéraire, Paris, Connecticut; Presses Univesitaires de France, Yale University Press, 1954.

MILES, Robert: The Great Enchantress, Manchester, Manchester U.P., 1995.

MolinA, José Luis: Anticlericalismo y literatura en el siglo XIX, Murcia, Universidad, 1998.

MOLINER, Antonio: «El anticlericalismo popular durante el bienio 1834-1835», Hispania Sacra, 49 (1997), pp. 497-541.

MOLINER, Antonio: «Opinión pública y anticlericalismo en la prensa exaltada del Trienio Liberal», en Lluís Roura y Juan F. Fuentes (coords.), Sociabilidad y liberalismo en la España del siglo XIX: homenaje al profesor Alberto Gil Novales, Lleida, Milenio, 2001, pp. 73-102.

MONTESINOS, José F.: Introducción a una historia de la novela en España en el siglo XIX. Seguida del esbozo de una bibliografía española de traducciones de novelas 1800-1850, Madrid, Castalia, 1982.

MORANGE, Claude: «Teoría y práctica de la libertad de prensa durante el Trienio Constitucional: el caso de El Censor (1820-1822)», en Siete calas en la crisis del Antiguo Regimen español, Alicante, Diputación, Instituto de Cultura Juan GilAlbert, 1990.

MUÑOZ SEMPERE, Daniel: La Inquisición española como tema literario, Londres, Tamesis, 2008.

PegenAUTE, Luis: «La época romántica», en F. Lafarga y L.Pegenaute, Historia de la traducción en España, Ambos Mundos, 2004, pp. 321-396.

PORTE, Joel: «In the hands of an Angry God: Religious Terror in Gothic Fiction», en G.R. Thomson (ed.), The Gothic Imagination: Essays in Dark Romanticism, Washington State University Press, 1974, pp. 42-64.

RADCLIFFE, Ann: El confesonario de los penitentes negros, Madrid, Brugada, 1821.

RodRíGUeZ, Carlos M.: Frailes y revolución liberal, Toledo, Azacanes, 1996.

SEBOLD, Rusell P.: «Sadismo y sensibilidad en Cornelia Bororquia o la víctima de la Inquisición», en Actas del I Congreso Internacional sobre novela del siglo XVIII, Almería, Universidad, 1998, pp. 63-78.

TARR, Mary M.: Catholicism in Gothic Fiction, Washington,The Catholic University of America Press, 1966.

URRUTIA, Jorge: «El inicio de la novela anticlerical», en Cultura Hispánica y Revolución Francesa, Roma, Bulzoni, 1990, pp. 75-86.

VARMA, Devendra P. Varma: The gothic flame, New York, Russell \& Russell, 1966.

WERNER, Stephen: «Diderot, Sade and the gothic novel», Studies on Voltaire and the Eighteenth-Century, CXIV (1973), pp. 273-290. 